Connecticut College

Digital Commons @ Connecticut College

2009

\title{
Current and potential distributions of three non-native invasive plants in the contiguous USA
}

Chad C. Jones

Connecticut College, cjones8@conncoll.edu

Sarah Reichard

University of Washintgon

Follow this and additional works at: https://digitalcommons.conncoll.edu/botanyfacpub

Part of the Biodiversity Commons, Botany Commons, Plant Biology Commons, and the Plant Breeding and Genetics Commons

\section{Recommended Citation}

Jones, Chad C. and Reichard, Sarah, "Current and potential distributions of three non-native invasive plants in the contiguous USA" (2009). Botany Faculty Publications. 4.

https://digitalcommons.conncoll.edu/botanyfacpub/4

This Article is brought to you for free and open access by the Botany Department at Digital Commons @ Connecticut College. It has been accepted for inclusion in Botany Faculty Publications by an authorized administrator of Digital Commons @ Connecticut College. For more information, please contact bpancier@conncoll.edu.

The views expressed in this paper are solely those of the author. 
Current and potential distributions of three non-native invasive plants in the contiguous USA In Press, Natural Areas Journal

Chad C. Jones $^{\mathrm{a}, \mathrm{b}}$

College of Forest Resources, Box 352100

University of Washington

Seattle, WA 98195-2100 USA

Sarah Reichard

University of Washington Botanic Gardens, Box 354115

University of Washington, Seattle, WA 98195-4115

reichard@u.washington.edu

aAAuthor for correspondence; cjones8@conncoll.edu

${ }^{\mathrm{b}}$ Current address: Botany Department, Connecticut College, 270 Mohegan Ave. New London, CT 06320

Word Count: 6618

ABSTRACT: Biological invasions pose a serious threat to biodiversity, but monitoring for invasive species is time consuming and costly. Understanding where species have the potential to invade enables land managers to focus monitoring efforts. In this paper, we compared two simple types of models to predict the potential distributions of three non-native invasive plants (Geranium robertianum, Hedera spp., and Ilex aquifolium) in the contiguous USA. We 
developed models based on the climatic requirements of the species as reported in the literature (literature-based) and simple climate envelope models based on the climate where the species already occur (observation-based). We then compared the results of these models with the current species distributions. Most models accurately predicted occurrences, but overall accuracy was often low because these species have not yet spread throughout their potential ranges. However, literature-based models for Geranium and observation-based models for Ilex illustrated potential problems with the methodology. Although neither model type produced accurate predictions in all cases, comparing the two methods with each other and with the current species distributions provided rough estimates of the potential habitat for each species. More importantly, this methodology raised specific questions for further research to increase our understanding of invasion patterns of these species. Although these types of models do not replace more rigorous modeling techniques, we suggest that this methodology can be an important early step in understanding the potential distributions of non-native species and can allow managers of natural areas to be aware of potential invaders and implement early detection.

Index terms: Early detection; Invasive species; Habitat distribution models; Hedera helix; Hedera hibernica 


\section{INTRODUCTION}

Biological invasions are becoming a serious threat to biodiversity in the

USA (Wilcove et al. 1998) and throughout the world (Mack et al. 2000). Invading species can compete for resources with native species, alter nutrient and hydrological cycles, and change disturbance regimes (Mack et al. 2000).

To more effectively deal with this threat, considerable attention has been placed on detecting invasions at early stages, before extensive control is needed (National Invasive Species Council 2001). For early detection to be successful, extensive monitoring is necessary. However, monitoring for invasive species, especially when they are uncommon, is time consuming and costly (Rew et al. 2006). Therefore, approaches that focus monitoring efforts on areas most likely to be invaded will greatly reduce costs and provide the maximum benefit.

Research into the biological traits of species has shed some light on the potential to predict new invasions (Rejmánek and Richardson 1996, Reichard and Hamilton 1997). The knowledge that a species has been invasive in other areas with similar climate provides strong predictive power (Reichard and Hamilton 1997). Using this information, regions with similar climate parameters can be identified and monitoring efforts guided toward these areas.

At coarse scales, climate plays an important role in determining the distributions of plant species (Woodward 1987). Northern range limits (in the northern hemisphere) generally correspond with temperatures during the growing season (i.e., growing degree-days) and minimum winter temperatures (Woodward and Williams 1987). Water availability can limit distributions in dry areas and is often measured by the ratio of potential and actual evapotranspiration (Cramer and Prentice 1988) or by using precipitation as a surrogate (Woodward and Williams 1987). The relationship between climate and distributional limits in 
warm and wet areas is less straightforward and may reflect competitive interactions (Woodward and Williams 1987). Nevertheless, climate can provide a rough estimate of the potential distributions of species at large scales (Pearson and Dawson 2003).

There are many techniques for modeling the potential distributions of species (Guisan and Zimmermann 2000, Elith et al. 2006), but many of these are complex and require both specific data on current distributions and expertise with statistical modeling. One simple approach is to use climate envelope models to determine the climatic boundaries of a species' potential distribution. One way to build these models is to use information on the climate tolerances of a non-native species from the literature, expert opinion, or from climate and range maps from the species' native range. In general, most available information is from the native range. This information is then used to construct 'literature-based' models of the species' potential distribution. Knowledge of the location of specific occurrences is not necessary. For well-studied species this provides a simple and cost effective way to develop a coarse model of potential habitat. Only a few models of this type have been reported and methods vary (Weber 2001, Gillham et al. 2004).

More commonly, climate envelope models are developed using species distributional data, These models are simple compared to most other habitat distribution models and can be used with 'presence-only' data (Rouget et al. 2004). These 'observation-based' climate envelope models (e.g., BIOCLIM, Busby 1991) are created by determining the minimum and maximum values for each desired climate variable from a set of known locations (or the interval containing $95 \%$ of occurrences). These values are then set as the predicted distributional limits. This creates a multi-dimensional 'envelope' of suitable habitat. This approach can use known locations in the native range, but most studies have used known locations from the area of interest or other 
invaded areas (Chicoine et al. 1986, Robertson et al. 2004, Rouget et al. 2004). This latter approach can work well if the species has had sufficient time to spread to most available habitat in the invaded area.

In this study we developed models of potential distributions of three species currently invading natural areas in northwestern USA: Geranium robertianum L., Hedera helix L. and Ilex aquifolium L. All three are non-native species that can invade undisturbed forests and are therefore of great concern to land managers. Our objectives were to: 1) develop simple, literature-based models of the potential distribution of each species in the continental USA and compare these models to observation-based climate envelope models, 2) summarize the current distributions of these species for comparison with the predicted potential distributions, and 3) assess the value of this methodology as a simple early step for understanding distributional patterns of non-native species and monitoring their spread.

\section{METHODS}

Study Species

\section{Geranium robertianum}

Geranium robertianum (herb Robert) is an annual or biennial herb. It can colonize a wide range of habitats, from closed forest to open scree and rocks, although more robust plants are generally found in open forests with moderately moist soils (Tofts 2004). It reproduces only by seeds, which can remain dormant for up to five years (Bertin 2001). Seeds are ejected up to 6.5 
$\mathrm{m}$ from the parent plant and have tangle threads and can be dispersed by animals or by water (Grime et al. 1988, Tofts 2004).

Geranium is native to Europe and the British Isles, from sea level to altitudes of $2700 \mathrm{~m}$, and has been introduced to many parts of the world including, Japan, China, the western Himalaya, Chile, New Zealand, and Australia (Tofts 2004). In the USA it is an aggressive invader in western Oregon and Washington, where it has been present since at least 1906 . In the northeastern USA, the situation is less clear, with some sources citing it as non-native (Gleason and Cronquist 1963, Rickett 1966) and others as native (Fernald 1950, Seymour 1969).

The ecological impacts of Geranium are not well studied, but in the Pacific Northwest it can spread rapidly and quickly attain 50-100\% cover over large areas (Tisch 1992). Because it can germinate in deep shade and remain green over winter, it has the potential to outcompete native forest herbs (Tisch 1992). There are some data suggesting that it is allelopathic (Barndt 2008).

Hedera helix and Hedera hibernica

Hedera helix (English ivy) is reported to invade many parts of the world, but these reports may include a closely related species, Hedera hibernica (G. Kirchn.) Bean (Atlantic ivy). Morphologically the two species can only be distinguished based on such characteristics as patterns of leaf hairs. Stace (1997) considers $H$. hibernica to be a subspecies of $H$. helix, while others consider it to be a separate species (McAllister and Rutherford 1990, Ackerfield and Wen 2003). In the Pacific Northwest, most individuals that invade natural areas are the tetraploid $H$. hibernica (Ramsey 2005, Clarke et al. 2006), while in the eastern USA, diploid H. helix is the

more common invader (T. F. Ramsey, University of Rochester, unpublished data). Because both 
species can invade natural areas, but have not been distinguished in most cases, we combine them for the purposes of this paper (hereafter referred to as Hedera).

Both species are evergreen vines that occur in both deep shade and more open areas (Metcalfe 2005). Hedera reproduces both by seeds and aggressive vegetative spread (Grime et al. 1988) and individual plants can live for at least 400 years (Rose 1996). Hedera fruits are eaten by many species of birds and can be dispersed long distances (Van Ruremonde and Kalkhoven 1991).

The native range of Hedera helix extends from Norway to northern Africa and east to the Ukraine, while H. hibernica is restricted to coastal areas of western Europe (Metcalfe 2005). Hedera invades Australia, Brazil, and New Zealand as well as Hawaii, the Pacific Northwest, Mid-Atlantic, and southern states of the USA (Metcalfe 2005). It has been planted in the USA since at least 1727 (Rose 1996).

Although Hedera often covers trees, there is only limited evidence of direct tree mortality as a result (Thomas 1980, Metcalfe 2005). However, Hedera can carpet the forest floor, and negatively impact both understory species and tree seedlings (Thomas 1980, Dlugosch 2005).

\section{Ilex aquifolium}

Ilex aquifolium (English holly), is an evergreen tree or large shrub that can grow in both open and shaded areas (Peterken 1966). Ilex individuals can live for at least 250 years and reproduce mainly by seeds (Peterken and Lloyd 1967). Ilex seeds can be dispersed long distances by birds (Peterken and Lloyd 1967) and can persist in the seed bank for 4-5 years (Arrieta and Suarez 2004). 
Ilex is native to the forests of Great Britain and Europe, as far south as northern Africa and southwest Asia (Peterken and Lloyd 1967). It is a widely distributed ornamental and is known to be invasive in Australia and New Zealand, as well as parts of temperate east and west North America (Weber 2003). In the Pacific Northwest of the USA, it has been grown in commercial orchards since the late $19^{\text {th }}$ century both as a landscape plant and as a Christmas decoration (Wieman 1961).

Despite its long history of use, less is known about its impacts on invaded habitats than Geranium or Hedera. Ilex aquifolium is shade-tolerant and creates a tall evergreen shrub layer not found in many forests it invades. It also casts deep shade all year which may reduce plant regeneration beneath its canopy (Peterken 1966).

\section{Current Distributions}

We gathered information on the current distribution of each species in the contiguous United States (the invaded range) from a variety of sources including herbarium records, plant atlases and personal communications (Appendix A). Species records were used for model development if the specific location was reported with precision of at least $1 \mathrm{~km}$ and was at least $1 \mathrm{~km}$ from any other record. Many of the sources indicated presence within a county rather than a specific location. These records were used to assess model accuracy but were not included in model development because of the variation in climate within individual counties.

\section{Potential Distribution Maps}

At a broad scale, the distributions of plant species are typically limited by winter low temperatures, temperatures over the growing season, and moisture availability (Cramer and 
Prentice 1988, Shafer et al. 2001). We searched the literature for information on the climatic requirements of each species, focusing on these three characteristics (see Study Species above). We then used these climatic requirements to create literature-based models of the potential distribution of each species in the USA. The actual climate variables used (Table 1) depended on the available information for each species and the climate variables available as GIS layers for the contiguous USA. Data for many climate variables for the contiguous USA are available at 1 km resolution from DAYMET using climate data averaged from 1980-1997 (www.daymet.org, Thornton et al. 1997).

We developed observation-based models by using the range of climate conditions at current known locations to construct a model of suitable climate. For each species, we determined the values of each climate variable used in the literature-based models at each location where the species occurred. We then calculated distributional limits as the minimum and maximum values for each climate variable among all of the specific locations (henceforth "EnvAll" models) or with the 5\% most extreme values for each variable removed (henceforth “Env95”). This procedure for developing observation-based climate envelope models is similar to that used by BIOCLIM models (Busby 1991), but does not require the purchase of specialized software.

For both model types we classified each $1 \mathrm{~km}$ cell in the contiguous USA as suitable for a species if the values for all of the climate variables were within the suitable range determined for that model. If any of the climate variables fell outside the range, the cell was considered unsuitable.

\section{Geranium robertianum}


Tofts (2004) reports distributional limits for Geranium for maximum July temperature (mean of the daily maximum values), for minimum January temperature (mean of the daily minimum values), and for annual precipitation. Because Tofts (2004) expressed uncertainty over the upper limit for maximum July temperatures, we created three models using the $25^{\circ} \mathrm{C}$ reported (Table 1; Lit1), then relaxing the limit to $27.5^{\circ} \mathrm{C}$ (Lit2) and $30^{\circ} \mathrm{C}$ (Lit3). We produced observation-based models from 87 known locations in the contiguous USA.

\section{Hedera helix and Hedera hibernica}

Iverson (1944) presents distributional limits for Hedera based on mean temperatures of the coldest and warmest months. Although Hedera did not reproduce at mean temperature of the coldest month $<-2.5^{\circ} \mathrm{C}$, it can survive to $-8^{\circ} \mathrm{C}$ (Iverson 1944), thus we created a second model with this limit (Table 1; Lit3). The limit for annual precipitation was based on two sources. First, Muyt (2001) states that Hedera is only invasive in Australia in areas with $>700 \mathrm{~mm}$ annual precipitation. Second, the eastern range limit of Hedera in Europe and Asia (Hultén and Fries 1986) extends to between 600 and $700 \mathrm{~mm}$ annual precipitation (Steinhauser 1970). We mapped the potential distribution of Hedera at both annual precipitation $>700 \mathrm{~mm}$ (Table 1; Lit1 and Lit3) and >600 mm (Lit2). We created observation-based models from 59 known locations in the contiguous USA.

\section{Ilex aquifolium}

Distributional limits for Ilex were reported in the literature based on a moisture index (actual/potential evapotranspiration [AET/PET]), growing degree days (GDD, base $5^{\circ} \mathrm{C}$ ), and mean temperature of the coldest month (Iverson 1944, Prentice and Helmisaari 1991). 
Unfortunately, climate layers for the first two variables were available only at a $25 \mathrm{~km}$ resolution and were based on climate measurements from 1951-1980 (Shafer et al. 2001). Thus it was necessary to convert the distributional limits to variables that were available at $1 \mathrm{~km}$ resolution (annual precipitation and GDD base $0^{\circ} \mathrm{C}$, respectively).

To convert the distribution limits for moisture index (only available at $25 \mathrm{~km}$ resolution) to annual precipitation (available at both 1 and $25 \mathrm{~km}$ resolutions) we used linear regression of the values for both variables for each $25 \mathrm{~km}$ grid cell for the contiguous USA. We then used the regression to calculate the 95\% confidence interval for annual precipitation at the distribution limit for the moisture index reported in the literature $(\mathrm{AET} / \mathrm{PET}=0.64)$. The lower bound of this confidence interval (annual precipitation $=709.5 \mathrm{~mm}$ ) was then used as the distributional limit. The $\mathrm{R}^{2}$ for this regression was only 0.624 , but the precipitation limit compared favorably with the southeastern boundary of the European range of Ilex, which extends to about $700 \mathrm{~mm}$ annual precipitation (Steinhauser 1970, Hultén and Fries 1986). A similar conversion process was used to convert the distribution limit for growing degree days from base $5^{\circ} \mathrm{C}$ (data from Shafer et al. 2001) to base $0^{\circ} \mathrm{C}$ (data from DAYMET). For this conversion we first reduced the resolution of the DAYMET data to $25 \mathrm{~km}$ by averaging all of the $1 \mathrm{~km}$ cells within each $25 \mathrm{~km}$ cell. We then created the linear regression model $\left(\mathrm{R}^{2}=0.967\right)$.

Both the change in resolution and the difference in timing of climate data collection could lead to errors. To test for this we compared the predicted distribution of Ilex using the original variables at the $25 \mathrm{~km}$ scale with the distribution using the converted values at the $1 \mathrm{~km}$ scale. The predicted distributions from the two methods were almost identical, so the conversion did not introduce bias in the resulting distribution. We created observation-based models from 42 known locations in the contiguous USA. 
Comparison of Current and Potential Distributions

To assess the accuracy of the potential distributions predicted by the models, we compared these distributions with the current county-level distributions of the species. Countyscale distributions were used as they provide a more complete record of the current species distributions (specific locations were not available for many counties where the species occur). A county was assumed to be suitable for the species if any point in the county was modeled as having suitable climate.

We used three measures to assess model accuracy: Sensitivity, Specificity and the True Skill Statistic (TSS). Sensitivity is the proportion of occurrences accurately predicted by a model while Specificity is the proportion of absences accurately predicted by a model (Fielding and Bell 1997). Both Sensitivity and Specificity can range from 0 (completely inaccurate) to 1 (perfect accuracy). TSS is a measure of overall model accuracy and is calculated as Sensitivity + Specificity -1 . TSS is equivalent to the more commonly used Kappa statistic when frequencies of presence and absence points are equal, but unlike Kappa, it is not sensitive to frequency (Allouche et al. 2006). Values $>0.6$ are considered good, 0.2-0.6 fair to moderate, and $<0.2$ poor (Landis and Koch 1977).

\section{RESULTS}

Geranium robertianum

Geranium was reported from 249 counties, mostly in the northeastern USA and along the west coast (Fig. 1). The literature-based model (Lit1) did not correspond well to the current 
distribution. Sensitivity (0.47) and TSS (0.33) were both low for this model (Table 2), which predicted that many areas where the species currently occurs were not suitable. Increasing the July maximum temperature threshold to $27.5^{\circ} \mathrm{C}$ or $30^{\circ} \mathrm{C}$ increased Sensitivity and TSS but also reduced Specificity (Table 2). As expected, observation-based models had high Sensitivity because they were based on the current distribution of the species (although not the same set of data used to assess the models). The Env95 model also had the highest overall accuracy of all of the models for Geranium (TSS=0.59; Table 2). The distributions predicted by observation-based models were different than for the literature-based models, particularly in the north central USA

(Fig. 1). Thus the current distribution of Geranium in the USA does not correspond well with the climate tolerances reported in the literature. Geranium is currently reported from 14.1 to $23 \%$ of the counties that are predicted to be suitable, depending on the model.

Hedera helix and Hedera hibernica

Hedera was reported from much of the eastern USA and along the west coast (Fig. 2). It was most common in the Mid-Atlantic States and the Pacific Northwest, but there were also isolated occurrences in the upper Midwest and the Southwest. The literature-based model (Lit1) predicted suitable climate for Hedera in the southeastern USA and along the West Coast with some scattered areas in the Rocky Mountains (Fig. 2). All of the literature-based models had high Sensitivity, but poor to moderate Specificity and overall accuracy (TSS; Table 2). Adding areas where the minimum January temperature was between -2.5 and $-8^{\circ} \mathrm{C}$ (Lit3) led to perfect prediction of occurrences (Sensitivity $=1$ ) but lower overall accuracy, and reports suggest that Hedera was not reproductive in these areas (Ramsey 2005). Adding areas with lower annual precipitation (Lit2) also reduced model accuracy. Several occurrences in the Southwest were in 
areas with low precipitation, but these were restricted to riparian areas or were planted (Ramsey 2005).

Observation-based model results were generally similar to the literature-based model (Fig. 2). However, when all locations were included (EnvAll), results were affected by the specimens from riparian areas in the arid Southwest, and thus dry areas were predicted to be suitable, leading to poor Specificity and TSS (Fig. 2, Table 2). Overall model accuracy (TSS) was highest in the basic literature-based model (Lit1). However, in all models, Hedera was only reported in 9 to $12.4 \%$ of the counties with predicted suitable climate, leading to moderate to low overall accuracy.

Ilex aquifolium

Ilex was reported in 26 counties in the Pacific Northwest and one in southern California. There were also records from two national parks in the eastern USA but it was not certain if these were planted. The literature-based model predicted that areas along the west coast and in the eastern USA were suitable climates (Fig. 3). Sensitivity was high, while Specificity and TSS were moderate (Table 2) because large areas in the eastern USA are predicted to be suitable, but have not been invaded.

Observation-based models were very different from each other and from the literaturebased models (Fig. 3). These differences are due to two occurrences of Ilex in areas with very different climates from the rest of the occurrences: in eastern Washington, in an area with cold January temperatures and in an area of southern California with low annual precipitation. It is not clear if these are naturalized or were planted. When these two locations were included (EnvAll), most of the eastern and central USA was predicted to be suitable, leading to very low Specificity 
and TSS (Table 2). When the two outliers were removed (Env95), only a small area in the eastern USA was predicted to be suitable and Specificity and TSS were both high (Table 2). Ilex was reported as present in very little of its predicted range (1.2 to 8.5\%, Table 2).

\section{DISCUSSION}

Of the three species, the literature-based model was least accurate for Geranium, which occurs in many areas (e.g., Ohio, Pennsylvania, and others) with warmer summers than the temperature limit suggested by Tofts (2004). In addition, comparison with observation-based models indicate that Geranium does not currently occur in habitats in the USA that are as cold or dry as reported from its native range (Tofts 2004). For example, the literature-based model suggests that Geranium could occur in areas with very cold winters such as in north-central USA. The disparity between predicted and current distributions may simply reflect uncertainty about its environmental tolerances, but could also be due to genetic differences or important variables not included in the models. Alternatively, it could suggest that Geranium has the potential to colonize many additional areas in the USA.

Even the most restrictive models predict that there are many suitable areas where Geranium does not currently occur, particularly in the Rocky Mountains. Only one population of Geranium is reported from this region (in Missoula, Montana). This population, however, is showing signs of aggressive spread, so land managers in the northern Rocky Mountains should be aware of its potential to spread in this area.

Models for Hedera accurately predicted most current occurrences, but overall accuracy was low. Nevertheless, the extent of the current distribution corresponded well with predicted distributions (Fig. 2). These results emphasize the limitations of metrics of model accuracy that 
include absences (i.e., Specificity and TSS). Absences may indicate either that the climate is not suitable or that the species has not yet invaded that area (or has not yet been reported). Thus, these metrics must be used with care. The low Specificity and TSS for the Hedera models is likely because the species has either not spread throughout the southeastern USA and/or that reporting from this area is not complete.

Although Hedera was reported from much of the eastern USA, it is currently viewed as a problem species only on the west coast and in the Mid-Atlantic States. Competition from other non-native vines (e.g., Pueraria montana (Lour.) Merr.) may limit its impact in many of the southern states (Ramsey 2005). In addition, Hedera currently occurs mostly near urban and suburban areas where it has been planted. Only in the Pacific Northwest and Mid-Atlantic States has Hedera spread into undisturbed forest habitat away from populated areas. However, since Hedera has the potential for long distance seed dispersal by birds, it may spread into undisturbed forests elsewhere in the USA in the future. Thus land managers in the southeastern USA should be aware of the potential of Hedera to invade.

Ilex is just beginning to be recognized as a potential invader, particularly in the Pacific Northwest, where there has been a long history of cultivation. The literature-based model suggests that Ilex has the potential to invade a large part of the eastern USA, but to this point it has been reported only from single locations in Massachusetts and Maryland. Ilex may have had fewer opportunities to escape in the eastern USA because it is not as extensively cultivated there. However, there are also several species of Ilex that are native to the eastern USA, thus the competitive environment may be very different from that in the Pacific Northwest, and may prevent invasion. More research is clearly needed, but land managers in the eastern USA should report Ilex aquifolium if it is found on their land 
Literature-based models

Although each species presents unique challenges, creating literature-based models of potential distributions of non-native species can be a useful approach. These models provide a first approximation of the potential distribution of a species without requiring detailed information about species presence and absence. Thus it could be used when specific location data or modeling expertise are lacking.

There are two important caveats to this approach. First, it will only work for species for which there is information about their environmental tolerances. This may pose a problem for many species native to regions that have been poorly studied. However, this approach should work well for many European species. Second, these models provide a rough approximation of potential habitat. They do not consider dispersal, disturbance, land use, herbivory, competition, soil conditions or many other factors. They also do not consider interactions among climate variables. Thus, a species should not be expected at all locations predicted to have suitable climate. Conversely, there may be areas outside of the modeled habitat where a species can occur because of locally suitable conditions. This is apparent for Hedera, which can invade riparian zones in areas where annual precipitation is too low.

Despite these limitations, literature-based models can provide two important benefits. They can be used to define the potential ranges of species and thus help land managers determine if a species may invade in their area. Second, they can lead to specific questions about the factors that control the species' distributions and suggest directions for future research. For example, can Geranium survive extreme winter temperatures in the north central USA? Is the lack of Ilex invasion in the eastern USA due to competitive interactions, environment, or lack of dispersal? 
Observation-based envelope models

Climate envelope models that use current distributional data from the invaded range can be used to determine if there are un-invaded areas that are climatically similar to areas already invaded. Because genotypes in the invaded range may differ from those in its native range (Leger and Rice 2003), this may more accurately reflect the potential of the species to spread in the invaded area. However, there are also several weaknesses of this approach. First, these models can be extremely sensitive to outliers as illustrated by predictions for Ilex. Second, observationbased models can also be affected by sampling patterns or invasion history. For Ilex, most reported locations are from Oregon and therefore from a fairly narrow climatic range that may or may not reflect the potential climatic range of the species across the broader area of interest (Loo et al. 2007). Because there was only one specific location for Ilex in the eastern USA, predicting potential habitat in that region is greatly limited. Thus, these models are less useful when species are uncommon in the area of interest. Third, these models do not explicitly consider interactions between climate variables. For example, a species may be able to survive higher temperatures as long as there is sufficient precipitation. This could be solved by using climatic variables such as a moisture index that considers both temperature and precipitation, but these are usually not available at a fine resolution over large areas.

Nevertheless, these models can suggest future information needs. Increased sampling in underrepresented areas would greatly improve model results. For these models to be useful it is important to examine occurrences at the climatic extremes to determine if these occurrences accurately reflect climate tolerances. 
Results from observation-based models emphasize the importance of data quality. There is much information on the distributions of non-native species available from the internet and in published material. However, data quality, availability, and format vary greatly by state. It would be beneficial to have a centrally located and standardized database for species distribution on at least a county scale. There are attempts to develop this, such as the Global Biodiversity Information Facility (www.gbif.org) and the USDA Plants Database (USDA-NRCS 2007), and these efforts should be expanded.

Conclusions

Combining literature-based and observation-based models is a fairly simple approach to modeling that can provide valuable insights into the potential distributions of non-native species. In addition to the individual benefits of each method, combining the two can identify suitable climate conditions that have not yet been invaded. These may occur simply due to lack of dispersal or they may reflect genetic differences between individuals in the native and invaded ranges or changes in species interactions (Broennimann et al. 2007). Depending on the sources used, literature-based model may reflect either the fundamental niche of the species or the realized niche given the species interactions in the native range. Observation-based models, however, reflect the realized niche based on species interactions in the invaded range. Thus differences between the two model types may reflect differences in the realized niche of the species due to differences in species interactions or differences in the fundamental niche due to genetic changes (Broennimann et al. 2007). Disparities between literature-based and observationbased models can thus lead to hypotheses and further studies of the factors that limit invasions. 
There are other more sophisticated methods for modeling potential distributions of nonnative species (Guisan and Zimmermann 2000), but the combination of literature-based and observation-based models provides a reasonable first approximation, while requiring less information and expertise. The information can help with regional planning, as cooperating land managers determine species to prioritize when using a landscape-level strategy. When more sophisticated, statistical modeling is done, these simple models provide a simple basis for comparison and have the potential to provide valuable insights into the modeling process. We suggest that this approach be considered as a potential tool for studying and monitoring nonnative species.

National strategies emphasize early detection of invasive species in new locations to facilitate rapid and effective control responses (National Invasive Species Council 2001). There are many challenges to doing this effectively; including prioritizing species of concern and training volunteer 'citizen scientists' to recognize a potentially large number of invasive plant species. Literature- and observation-based models of species that have been damaging in other regions could help restrict that number to an amount manageable for volunteer training. This approach could also be used by the U.S. Forest Service’s Forest Inventory and Analysis National Program (FIA), by training surveyors to recognize potential forest invaders in their region. Thus FIA could become an important part of national early detection efforts.

Developing literature- and observation-based model of invasive species will allow land managers to develop watch lists, determine which areas are more likely to be invaded, and will help identify future data and research needs. Thus we recommend that this approach be considered as an early step in understanding the potential distributions of invasive species. 


\section{ACKNOWLEDGEMENTS}

We thank Charles Halpern and his lab group for helpful comments on drafts of this manuscript. Tara Ramsey provided valuable comments and information on Hedera helix and Hedera hibernica. Funding for this project came in part from Olympic National Park (PNW CES Agreement CA9088A0008).

Chad Jones conducted this research as a research ecologist at the University of Washington. He is now an assistant professor of botany and environmental studies at Connecticut College.

\section{LITERATURE CITED}

Ackerfield, J., and J. Wen. 2003. Evolution of Hedera (the ivy genus, Araliaceae): insights from chloroplast DNA data. International Journal of Plant Sciences 164:593-602.

Allouche, O., A. Tsoar, and R. Kadmon. 2006. Assessing the accuracy of species distribution models: prevalence, kappa and the true skill statistic (TSS). Journal of Applied Ecology 43:12231232.

Arrieta, S., and F. Suarez. 2004. Germination and seed bank depletion of holly (Ilex aquifolium L.) in four microhabitat types. Seed Science Research 14:305-313.

Barndt, K. 2008. An assessment of the allelopathic potential of herb Robert (Geranium robertianum). M.S. thesis. University of Washington, Seattle. 
Bertin, R.I. 2001. Life cycle, demography, and reproductive biology of herb Robert (Geranium robertianum). Rhodora 103:96-116.

Broennimann, O., U.A. Treier, H. Muller-Scharer, W. Thuiller, A.T. Peterson, and A. Guisan. 2007. Evidence of climatic niche shift during biological invasion. Ecology Letters 10:701-709.

Busby, J.R. 1991. BIOCLIM — a bioclimatic analysis and prediction system. Pp. 64-68 in C.R. Margules and M.P. Austin, eds., Nature conservation: cost effective biological surveys and data analysis. CSIRO, Melbourne, Australia.

Chicoine, T.K., P.K. Fay, and G.A. Nielsen. 1986. Predicting weed migration from soil and climate maps. Weed Science 34:57-61.

Clarke, M.M., S.H. Reichard, and C.W. Hamilton. 2006. Prevalence of different horticultural taxa of ivy (Hedera spp. Araliaceae) in invading populations. Biological Invasions 8:149-157.

Cramer, W., and I.C. Prentice. 1988. Simulation of regional soil moisture deficits on a European scale. Norsk Geografisk Tidsskrift 42:149-151.

Dlugosch, K.M. 2005. Understory community changes associated with English ivy invasions in Seattle's urban parks. Northwest Science 79:52-59.

Elith, J., C.H. Graham, R.P. Anderson, M. Dudik, S. Ferrier, A. Guisan, R.J. Hijmans, F. Huettmann, J.R. Leathwick, A. Lehmann, J. Li, L.G. Lohmann, B.A. Loiselle, G. Manion, C. 
Moritz, M. Nakamura, Y. Nakazawa, J.M. Overton, A.T. Peterson, S.J. Phillips, K. Richardson, R. Scachetti-Pereira, R.E. Schapire, J. Soberon, S. Williams, M.S. Wisz, and N.E. Zimmermann. 2006. Novel methods improve prediction of species' distributions from occurrence data.

Ecography 29:129-151.

Fernald, M.L. 1950. Gray's manual of botany, 8th edition. Dioscorides Press, Portland, Oregon.

Fielding, A.H., and J.F. Bell. 1997. A review of methods for the assessment of prediction errors in conservation presence/absence models. Environmental Conservation 24:38-49.

Gillham, J.H., A.L. Hild, J.H. Johnson, E.R. Hunt, and T.D. Whitson. 2004. Weed Invasion Susceptibility Prediction (WISP) model for use with geographic information systems. Arid Land Research and Management 18:1-12.

Gleason, H.A., and A. Cronquist. 1963. Manual of vascular plants of the northeast United States and adjacent Canada. D. Van Norstrand Co. Inc., New York.

Grime, J.P., J.G. Hodgson, and R. Hunt. 1988. Comparative plant ecology: a functional approach to common British species. Unwin Hyman, London, UK.

Guisan, A., and N.E. Zimmermann. 2000. Predictive habitat distribution models in ecology. Ecological Modelling 135:147-186. 
Hultén, E., and M. Fries. 1986. Atlas of North European vascular plants: north of the Tropic of Cancer. Koeltz Scientific Books, Königstein, Germany.

Iverson, J. 1944. Viscum, Hedera and Ilex as climate indicators. Geologiska Föreningens I Stockholm Förhandlingar 66:463-483.

Landis, J.R., and G.G. Koch. 1977. The measurement of observer agreement for categorical data. Biometrics 33:159-174.

Leger, E.A., and K.J. Rice. 2003. Invasive California poppies (Eschscholzia californica Cham.) grow larger than native individuals under reduced competition. Ecology Letters 6:257-264.

Loo, S.E., R. MacNally, and P.S. Lake. 2007. Forecasting New Zealand mudsnail invasion range: model comparison using native and invaded ranges. Ecological Applications 17:181-189.

Mack, R.N., D. Simberloff, W.M. Lonsdale, H. Evans, M. Clout, and F.A. Bazzaz. 2000. Biotic invasions: causes, epidemiology, global consequences and control. Ecological Applications 10:689-710.

McAllister, H.A., and A. Rutherford. 1990. Hedera helix L. and H. hibernica (Kirchner) Bean (Araliaceae) in the British Isles. Watsonia 18:7-15.

Metcalfe, D.J. 2005. Hedera helix L. Journal of Ecology 93:632-648. 
Muyt, A. 2001. Bush invaders of South-East Australia: a guide to the identification and control of environmental weeds found in South-East Australia. RG \& FJ Richardson, Meridith, Victoria, Australia.

National Invasive Species Council. 2001. Meeting the invasive species challenge: national invasive species management plan. National Invasive Species Council, Washington DC, USA.

Pearson, R.G., and T.P. Dawson. 2003. Predicting the impacts of climate change on the distribution of species: are bioclimate envelope models useful? Global Ecology and Biogeography 12:361-371.

Peterken, G. 1966. Mortality of holly (Ilex aquifolium) seedlings in relation to natural regeneration in the New Forest. Journal of Ecology 54:259-269.

Peterken, G.F., and P.S. Lloyd. 1967. Biological flora of the British Isles. Ilex aquifolium L. Journal of Ecology 55:841-858.

Prentice, I.C., and H. Helmisaari. 1991. Silvics of North European trees - compilation, comparisons and implications for forest succession modeling. Forest Ecology and Management 42:79-93.

Ramsey, T.F. 2005. Invasion of English ivy (Hedera spp., Araliaceae) into Pacific Northwest forests. PhD dissertation. University of Washington, Seattle. 
Reichard, S.H., and C.W. Hamilton. 1997. Predicting invasions of woody plants introduced into North America. Conservation Biology 11:193-203.

Rejmánek, M., and D.M. Richardson. 1996. What attributes make some plant species more invasive? Ecology 77:655-661.

Rew, L.J., B.D. Maxwell, F.L. Dougher, and R. Aspinall. 2006. Searching for a needle in a haystack: evaluating survey methods for non-indigenous plant species. Biological Invasions 8:523-539.

Rickett, H.W. 1966. Wild flowers of the United States Vol. 1. The northeastern states. McGrawHill Book Co., New York.

Robertson, M.P., M.H. Villet, and A.R. Palmer. 2004. A fuzzy classification technique for predicting species' distributions: applications using invasive alien plants and indigenous insects. Diversity and Distributions 10:461-474.

Rose, P.Q. 1996. The gardener's guide to growing ivies. Timber Press, Portland, Oregon.

Rouget, M., D.M. Richardson, J.L. Nel, D.C. Le Maitre, B. Egoh, and T. Mgidi. 2004. Mapping the potential ranges of major plant invaders in South Africa, Lesotho and Swaziland using climatic suitability. Diversity and Distributions 10:475-484. 
Seymour, F.C. 1969. The flora of New England; a manual for the identification of all vascular plants, including ferns and fern allies and flowering plants growing without cultivation in New England. C.E. Tuttle Co., Rutland, Vermont.

Shafer, S.L., P.J. Bartlein, and R.S. Thompson. 2001. Potential changes in the distributions of western North America tree and shrub taxa under future climate scenarios. Ecosystems 4:200215.

Stace, C. 1997. New flora of the British Isles., 2nd edition. Cambridge University Press, Cambridge.

Steinhauser, F., editor. 1970. Climatic atlas of Europe. World Meteorological Organization, Geneva, Switzerland.

Thomas, L.K.J. 1980. The impact of three exotic plant species on a Potomac island. U.S. Department of the Interior, Washington DC, USA.

Thornton, P.E., S.W. Running, and M.A. White. 1997. Generating surfaces of daily meteorological variables over large regions of complex terrain. Journal of Hydrology 190:214251.

Tisch, E. 1992. Alien weed threatens Olympic National Park. Voice of the Wild Olympics: Newsletter of the Olympic Park Associates 1:6. 
Tofts, R.J. 2004. Geranium robertianum L. Journal of Ecology 92:537-555.

USDA-NRCS. 2007. The PLANTS Database (http://plants.usda.gov). Accessed 7 March 2007. in. National Plant Data Center, Baton Rouge, Louisiana.

Van Ruremonde, R., and J.T.R. Kalkhoven. 1991. Effects of woodlot isolation on the dispersion of plants with fleshy fruits. Journal of Vegetation Science 2:377-384.

Weber, E. 2001. Current and potential ranges of three exotic goldenrods (Solidago) in Europe. Conservation Biology 15:122-128.

Weber, E. 2003. Invasive plant species of the world: a reference guide to environmental weeds. CABI Publishing, Oxon, UK.

Wieman, J.S. 1961. History of English holly (Ilex aquifolium) in Oregon and the Northwest. J.S. Wieman, Portland, Oregon, USA.

Wilcove, D.S., D. Rothstein, J. Dubrow, A. Phillips, and E. Losos. 1998. Quantifying threats to imperiled species in the United States. Bioscience 48:607-615.

Woodward, F.I. 1987. Climate and plant distribution. Cambridge University Press, Cambridge.

Woodward, F.I., and B.G. Williams. 1987. Climate and plant distribution at global and local scales. Vegetatio 69:189-197. 

Table 1. Climate variables used to create potential distribution models.

\begin{tabular}{|c|c|c|c|c|c|c|c|}
\hline Species & Model $^{\mathrm{a}}$ & $\begin{array}{c}\text { Max July temp } \\
\left({ }^{\circ} \mathrm{C}\right)\end{array}$ & $\begin{array}{c}\text { Min January } \\
\text { temp }\left({ }^{\circ} \mathrm{C}\right)\end{array}$ & $\begin{array}{c}\text { Annual precip. } \\
\text { (mm) }\end{array}$ & $\begin{array}{l}\text { Mean July } \\
\text { temp }\left({ }^{\circ} \mathrm{C}\right)\end{array}$ & $\begin{array}{c}\text { Mean January } \\
\text { temp }\left({ }^{\circ} \mathrm{C}\right)\end{array}$ & $\begin{array}{c}\mathrm{GDD}^{\mathrm{b}} \\
\text { (base } 0^{\circ} \mathrm{C} \text { ) }\end{array}$ \\
\hline \multirow[t]{5}{*}{ Geranium } & Lit1 & $>10,<25$ & $>-25$ & $>250$ & & & \\
\hline & Lit2 & $>10,<27.5$ & $>-25$ & $>250$ & & & \\
\hline & Lit3 & $>10,<30$ & $>-25$ & $>250$ & & & \\
\hline & EnvAll & $>19.9,<31.4$ & $>-15$ & $>443$ & & & \\
\hline & Env95 & $>20.4,<30.6$ & $>-13.1$ & $>705$ & & & \\
\hline \multirow[t]{5}{*}{ Hedera } & Lit1 & & & $>700$ & $>13$ & $>-2.5$ & \\
\hline & Lit2 & & & $>600$ & $>13$ & $>-2.5$ & \\
\hline & Lit3 & & & $>700$ & $>13$ & $>-8$ & \\
\hline & EnvAll & & & $>389$ & $>15.5$ & $>-5.5$ & \\
\hline & Env95 & & & $>551$ & $>15.7$ & $>-2.5$ & \\
\hline \multirow[t]{3}{*}{ Ilex } & Lit & & & $>710$ & & $>-1$ & $>2571,<6359$ \\
\hline & EnvAll & & & $>389$ & & $>-6.4$ & $>2542,<6446$ \\
\hline & Env95 & & & $>542$ & & $>1.1$ & $>3169,<4499$ \\
\hline
\end{tabular}

${ }^{\mathrm{a}}$ Lit1=literature-based model (Lit2 and Lit3 are modifications of the literature-based model), EnvAll=observation-based model with all locations included, Env95=observation-based model with 5\% most extreme locations for each variable removed. See methods for more details.

${ }^{\mathrm{b}}$ Growing degree-days 
Table 2. Measures of model accuracy.

\begin{tabular}{|c|c|c|c|c|c|}
\hline \multirow[b]{2}{*}{$\operatorname{Model}^{\mathrm{a}}$} & \multicolumn{2}{|c|}{ \# counties } & \multirow[b]{2}{*}{ Sensitivity } & \multirow[b]{2}{*}{ Specificity } & \multirow[b]{2}{*}{ TSS } \\
\hline & $\begin{array}{l}\text { Currently } \\
\text { present }\end{array}$ & $\begin{array}{l}\text { Predicted } \\
\text { suitable }^{\mathrm{b}}\end{array}$ & & & \\
\hline \multicolumn{6}{|c|}{ Geranium robertianum } \\
\hline Lit1 & 249 & 518 & 0.470 & 0.860 & 0.330 \\
\hline Lit2 & 249 & 873 & 0.751 & 0.760 & 0.511 \\
\hline Lit3 & 249 & 1534 & 0.992 & 0.550 & 0.542 \\
\hline EnvAll & 249 & 1752 & 0.992 & 0.474 & 0.466 \\
\hline Env95 & 249 & 1237 & 0.944 & 0.649 & 0.593 \\
\hline \multicolumn{6}{|c|}{ Hedera helix/hibernica } \\
\hline Lit1 & 235 & 1827 & 0.962 & 0.443 & 0.405 \\
\hline Lit2 & 235 & 1894 & 0.962 & 0.420 & 0.382 \\
\hline Lit3 & 235 & 2520 & 1.00 & 0.206 & 0.206 \\
\hline EnvAll & 235 & 2602 & 1.00 & 0.178 & 0.178 \\
\hline Env95 & 235 & 1932 & 0.962 & 0.408 & 0.370 \\
\hline \multicolumn{6}{|c|}{ Ilex aquifolium } \\
\hline Lit & 29 & 1221 & 0.966 & 0.612 & 0.577 \\
\hline EnvAll & 29 & 2417 & 1.00 & 0.227 & 0.227 \\
\hline Env95 & 29 & 318 & 0.931 & 0.905 & 0.801 \\
\hline
\end{tabular}

${ }^{a}$ Lit1=literature-based model (Lit2 and Lit3 are modifications of the literature-based model), EnvAll=observation-based model with all locations included, Env95=observation-based model with $5 \%$ most extreme locations for each variable removed. 
${ }^{\mathrm{b}} \mathrm{A}$ county is considered suitable if any part of the county contains habitat modeled as suitable. These values do not include counties with only cultivated specimens. 
Figure 1. Current and potential distribution of Geranium robertianum L. in the contiguous United States using literature-based (top) and observation-based models (bottom). Lit2 and Lit3 are modifications of the literature-based model (Lit1). Observation-based models include all locations (EnvAll) or have the 5\% most extreme locations for each variable removed (Env95). Shading indicates potential habitat according to the specific model. Black circles indicate the centroids of counties where Geranium currently occurs. Black triangles indicate either records from prior to 1975 (with no recent confirmation) or are cultivated specimens. Map projections are Lambert Equal-Area Azimuthal.

Figure 2. Potential and current distribution of Hedera helix/hibernica in the contiguous United States using literature-based (top) and observation-based models (bottom). Lit2 and Lit3 are modifications of the literature-based model (Lit1). Observation-based models include all locations (EnvAll) or have the 5\% most extreme locations for each variable removed (Env95). Black circles indicate the centroids of counties where Hedera currently occurs except for some large counties (such as in Arizona and southern California) where points where placed at actual species locations. Black triangles indicate reports that are (or likely are) cultivated specimens.

Figure 3. Potential and current distribution of Ilex aquifolium L. in the contiguous United States using literature-based (top) and observation-based models (bottom). Observation-based models include all locations (EnvAll) or have the 5\% most extreme locations for each variable removed (Env95). Black circles indicate the centroids of counties where Ilex currently occurs while black triangles indicate reports that are cultivated specimens. 

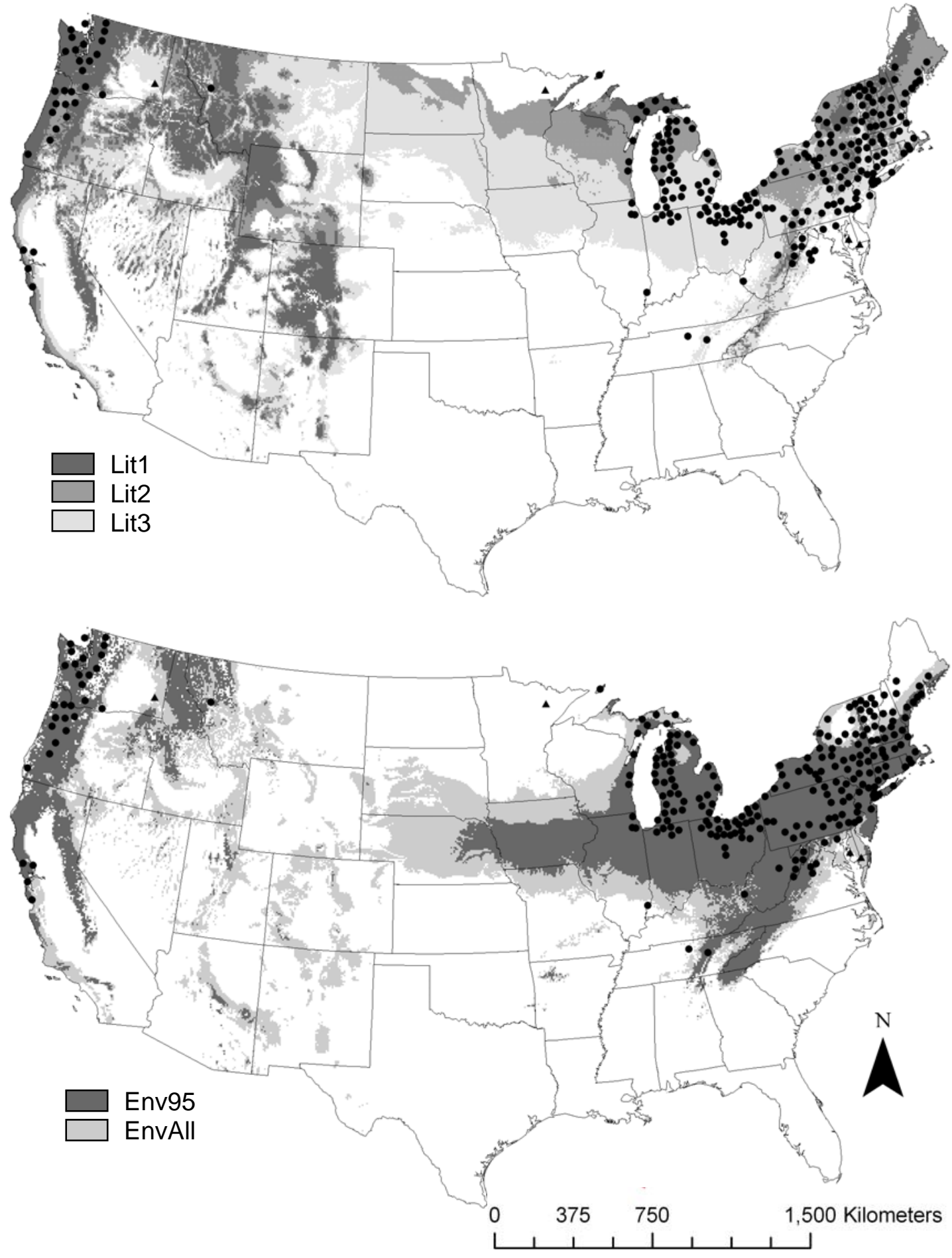

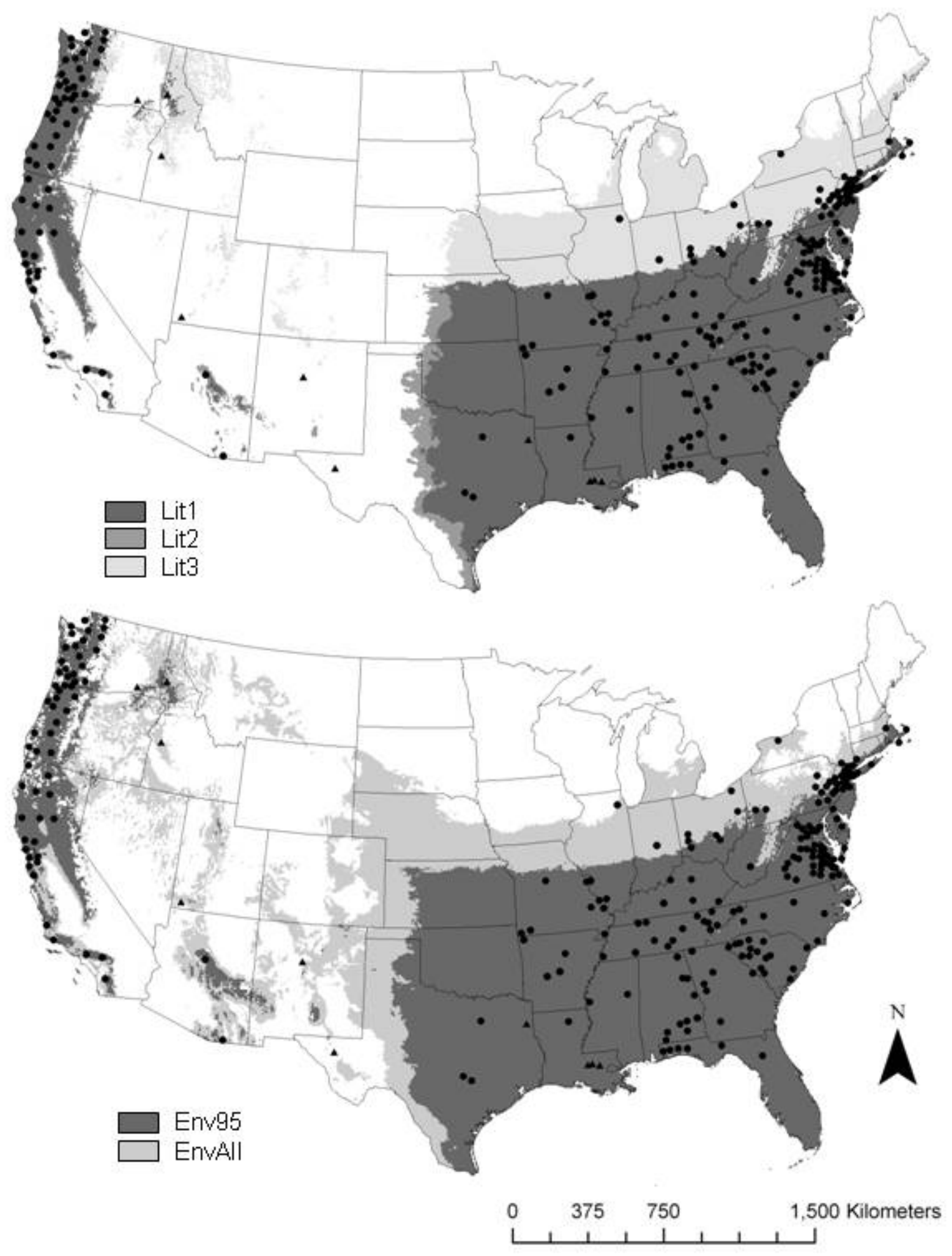

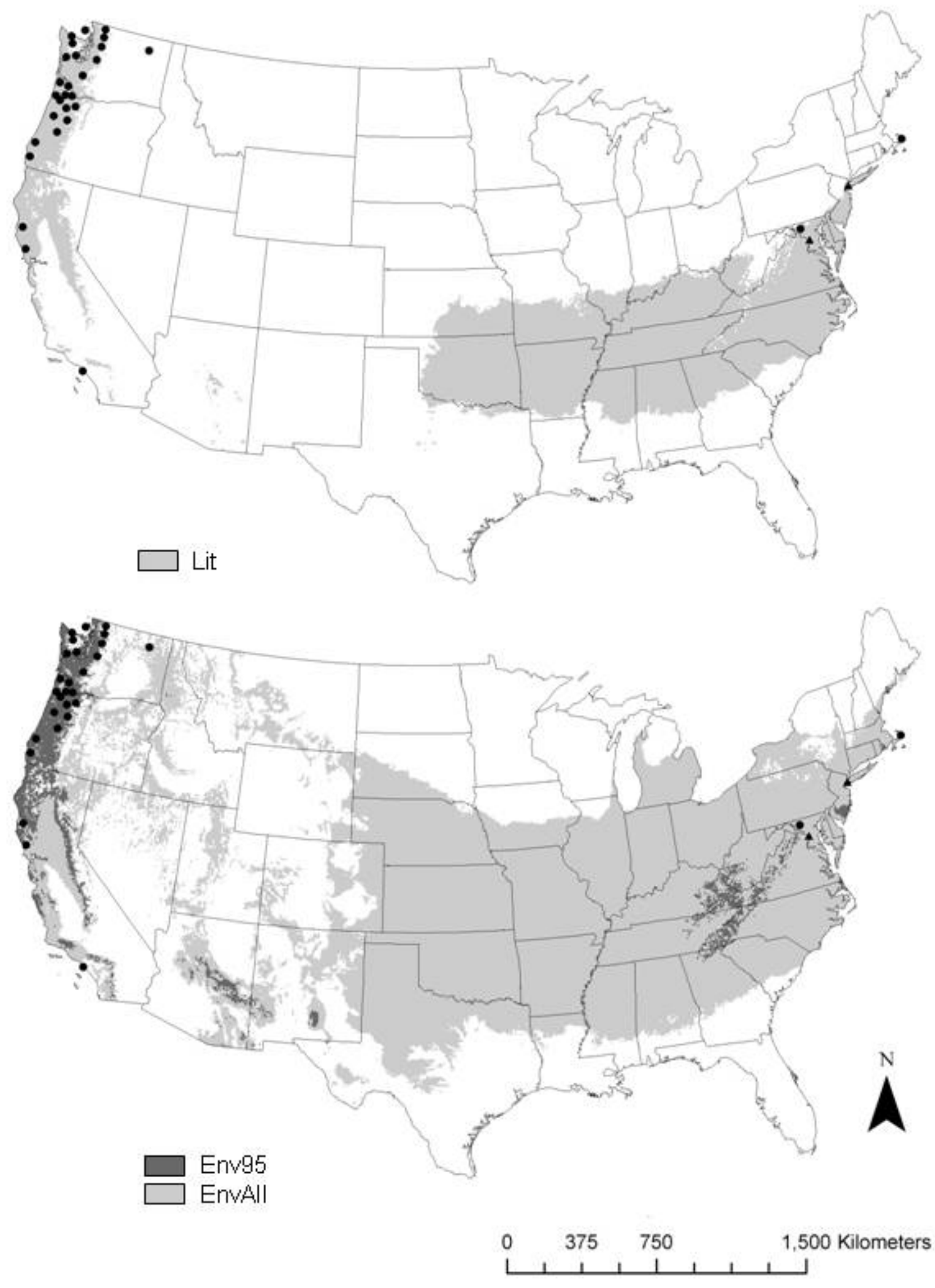
Appendix A. Major sources of information on the current distributions of Geranium robertianum, Hedera helix, and Ilex aquifolium. For a complete list of sources contact the author.

\section{National and Regional Online Sources}

USDA Plants Database (http://plants.usda.gov)

National Park Service - Alien Plant Working Group (http://www.nps.gov/plants/alien/)

Species in National Parks (http://www.ice.ucdavis.edu/nps/sbyname.html)

The Global Biodiversity Information Facility (www.gbif.org)

INVADERS Database - University of Montana (http://invader.dbs.umt.edu)

\section{State Plant Atlases and Herbarium Databases}

University of Arizona Herbarium (http://seinet.asu.edu/collections/selection2.jsp)

Brooklyn Botanic Garden Herbarium (http://www.bbg.org/sci/herbarium/)

Atlas of Florida Vascular Plants (http://florida.plantatlas.usf.edu/)

University of Florida Herbarium (http://www.flmnh.ufl.edu/herbarium/)

Illinois Plant Information Network (http://www.fs.fed.us/ne/delaware/ilpin/ilpin.html)

Consortium of California Herbaria (http://ucjeps.berkeley.edu/consortium/)

vPlants: virtual herbarium of the Chicago Region (http://www.vplants.org/index.html)

District of Columbia Herbarium (http://persoon.si.edu/dcflora/)

Louisiana State University Herbarium (http://www.herbarium.lsu.edu/search.php)

Online Atlas of Michigan Plants (http://herbarium.lsa.umich.edu/website/michflora/index.html)

University of Minnesota Herbarium (http://www.wildflowers.umn.edu/)

University of Mississippi Herbarium (http://www.herbarium.olemiss.edu/searchmissnew.php)

Missouri Botanical Garden - Tropicos (http://www.tropicos.org/) 
New York Flora Atlas (http://nyflora.org/atlas/atlas.htm)

University of North Carolina - Chapel Hill Herbarium (http://herbarium.unc.edu/data.htm)

Oregon Flora (www.oregonflora.org)

Pennsylvania Flora Project (http://www.paflora.org/)

University of South Carolina Herbarium (http://cricket.biol.sc.edu/herb/)

University of Tennessee Herbarium (http://tenn.bio.utk.edu/vascular/vascular.shtml)

Texas A\&M University Herbarium (http://www.csdl.tamu.edu/FLORA/biolherb/tamudata.htm)

Digital Atlas of the Virginia Flora (www.biol.vt.edu/digital_atlas)

Wisflora: Wisconsin Vascular Plant Species (http://www.botany.wisc.edu/wisflora/)

\section{Published Sources}

Aedo, C. 2000. The genus Geranium L. (Geraniaceae) in North America. I. Annual species. Anales del Jardin Botanico de Madrid 58:39-82.

Boersma, P. D., S. H. Reichard, and A. N. Van Buren, editors. 2005. Invasive species in the Pacific Northwest. University of Washington Press, Seattle, Washington, USA.

Cooperrider, T. S. 1995. The Dicotyledoneae of Ohio. Part 2. Linaceae through Campanulaceae. Ohio State University Press. Columbus, Ohio, USA

Mohlenbrock, R. H. 2002. Vascular Flora of Illinois. Southern Illinois University Press, Carbondale and Edwardsville, Illinois. USA

Ramsey, T. F. 2005. Invasion of English ivy (Hedera spp., Araliaceae) into Pacific Northwest forests. PhD dissertation. University of Washington, Seattle, Washington USA

Rhoads, A. F. \& W. M. Klein Jr. 1993. The vascular flora of Pennsylvania: annotated checklist and atlas. American Philosophical Society, Philadelphia, Pennsylvania, USA 